\title{
HOW DO MACROECONOMIC AND POLITICAL VARIABLES AFFECT THE FLEXIBILITY OF EXCHANGE RATE REGIME?
}

\author{
Research Assistant Dr.Mehmet Güçlü, Ege University, Faculty of Economics and \\ Administrative Siences, Department of Economics, mehmet.guclu@ege.edu.tr
}

\begin{abstract}
The choice of exchange rate regime has become one of the most important issues once more in many economies after the financial crises in recent years. In the wake of the financial crises, many countries, especially emerging market economies, opted for floating exchange rate regimes by forsaking the pegged regimes. Consequently, an old debate on the choice and determinants of exchange rate regimes has been triggered. Economists have started to debate what appropriate exchange rate regime for an economy is. When the tendency in recent years is taken into consideration, the choice of exchange rate regime of the countries, especially emerging economies, needs to be analyzed. To do this, in this paper, we attempt to uncover how emerging market economies choose their exchange rate regimes. In other words, we try to find the economic and political factors underlying the choice of exchange rate regimes. The study includes 25 emerging market economies over the period 1970-2006. We use random effect ordered probit model in order to find the long run economic and political determinants of exchange rate regimes for emerging economies. The determinants of both the de jure and de facto exchange regimes are empirically analyzed in the paper.
\end{abstract}

Key Words: Exchange Rate Regime, Emerging Market

\section{INTRODUCTION}

Following the financial crises in recent decade, many countries switched from one exchange rate regime to another (mostly rigid one to more flexible one). It has fueled the old debate on the choices and determinants of exchange rate regimes. Economists have started to argue what appropriate exchange regime for an economy is once more. Over the past 40 years, economists have developed various answers to this question. The first contribution to the debate 
came from optimum currency area (OCA) theory. It explains that how some macroeconomic aggregates of a country affect flexibility of an exchange rate regime to be adopted by that country. In the meanwhile, regime choices have also been discussed in terms of optimal stabilization policy, monetary policy credibility and currency crises. Since the second half of the 1990s, the empirical literature has tended to explain the role of political and institutional variables in regime choices (see Edwards, 1996; Breger et al., 2000). The empirical studies using political variables generally say that there is a negative correlation between political instability and exchange rate flexibility. The last contribution to the debate was made by Calvo and Reinhart with fear of floating in 2000. It has brought about to realize that there is a serious difference between de jure and de facto exchange rate regimes. The economists say that owing to fear of floating, some macroeconomic variables affect choices of regimes in an opposite direction to what the previous theories say. Besides, fear of floating creates a difference between what countries say and what countries do. Because of the difference between the de jure and de facto exchange regimes, the de facto regimes are also taken into account in this paper.

In order to explain the determinants of exchange rate regimes, empirical researchers have applied theoretical guidelines to the observed choices of exchange rate regimes. In doing this, most studies have employed the de jure regimes that the governments announce, while few studies have used the de facto regimes that they actually pursue. Until recently, the distinction between de jure and de facto regimes has mostly been ignored in the literature. The studies by Gosh et al. (1997), and Levy-Yeyati and Sturzenegger (1999, 2005), and Clavo and Reinhart (2000) developed some classification methods to determine type of exchange rate regime of a country in a specific year or period. They have reached that there was a serious difference between the de jure and de facto exchange rate regimes. Although why countries put into effect exchange rate regimes different from their official announcements remains a puzzle in the literature, it appears that the de facto classifications are more reliable than the de jure classifications.

Although there are many studies on the determinants of exchange rate regimes, there are no studies analyzing especially emerging market economies at least as far as we know. With this motivation, we analyze emerging market economies in this paper. Since most of the papers haven't used panel estimation method and / or disregarded the panel characteristics of data, their results may be misleading. In order to overcome this problem, we use random effect panel probit model in analyzing emerging market economies. The rest of the paper is organized as fallows. Section 2 presents the literature review. In section 3 and 4 , the data and estimation method are explained respectively. The empirical results are presented in the next section. The paper results in conclusion in section 6 . 


\section{LITERATURE REVIEW}

The empirical findings on the determinants of exchange rate regimes are numerous and controversial. The reason for the differences among the findings mostly depends on the country samples taken into consideration, time periods, regime classifications used in the analyses, estimation methods and assumptions of econometric models.

As stated before, the econometric methods and regime classifications used in the papers are different from each other. Thus, it creates different results. For instance, some of the studies (Edwards, 1998; Berger et. al; 2000; and Meon and Rizzo, 2002) used a simple binary structure to classify exchange rate regimes into either fixed or flexible ones while the others (Poirson, 2001; Zhou, 2003; and Von Hagen and Zhou, 2007) used an ordered-choice or multinomialchoice structure in order to classify the regimes. Besides, the studies also differs form each other in terms of estimation methods. A commonly used estimation method in the papers (Heller, 1978; Holden et el., 1979; Melvin, 1985; Edwards, 1998; Rizzo, 1998; Poirson, 2001; and Juhn and Mauro, 2002) is cross section analysis. Due to technical difficulties in the estimation of panel data models, especially due to the heavy computational burden of numerical integrations, panel data models are rarely implemented in the literature. Few of the studies in the literature (Zhou, 2003; Kato and Uctum, 2005, Von Hagen and Zhou 2007) employed panel data models in order to empirically analyze the determinants of exchange rate regimes.

The studies on the determinants of exchange rate regimes largely consist of the papers including the developing countries ( Rizzo, 1998; Breger et. al, 2000; Poirson, 2001; Zhou 2003; Von Hagen and Zhou, 2005, Bleaney and Francisco, 2005); or both the developing and developed countries (Meon and Rizzo, 2002; Juhn and Mauro 2002; Kato and Uctum, 2005, Levy-Yeyati and Sturzenegger, 2007). A few of the paper (Collins, 1996; Papaioannou, 2003; Markiewic, 2006) considered specific country groups such as Latin American countries, Central American countries, transition economies and etc. In the existing literature, as far as we know, there are no studies focused on emerging market economies. This motivates us to analyze emerging economies.

Most studies considered some of the optimum currency area variables, such as trade openness, size of economy, degree of economic development and geographical concentration of trade. In addition, some studies also included such macroeconomic variables as inflation, foreign exchange reserves, domestic credit, real exchange rate, and terms of trade. Also, a few studies contained political or institutional variables.

When the results of previous studies are considered, no results appear to be reasonably robust to changes in country coverage, sample period, estimation method, and exchange rate regime classification. For instance, trade openness is positively associated with the probability of adopting a flexible regime in the 
papers by Dreyer, 1978; Bernard and Leblang, 1999; Poirson, 2001; Juhn and Mauro, 2002; Von Hagen and Zhou, 2005, whereas it is negatively associated with the probability of adopting a flexible regime in the papers by Melvin, 1985; Rizzo, 1998; Berger et. al., 2000; and Meon, and Rizzo, 2002. Likewise, size of economy (Gross Domestic Product) is found to be positively associated with floating regimes in almost all studies, but not always significantly. Economic development (GDP per capita) is found to be significantly associated with floating regimes by four studies (Holden et. al.,1979; Savvides, 1990; Edwards, 1996, and Von Hagen and Zhou, 2005) significantly associated with fixed regimes by three studies ( Honkapojha and Pikkarainen, 1994; Edwards, 1999; Rizzo, 1998) and not significantly associated with any particular regime by another two studies (Collins, 1996, and Poirson, 2001). Inflation is always positively and significantly associated with floating except for one study (Von Hagen and Zhou, 2005). The similar results are valid for the other variables (the other macroeconomic, political and institutional variables). This suggests that the macroeconomic, political and institutional variables are not robust predictors of exchange rate regime choice. On the other hand, it doesn't mean this denies the potential importance certain variables for specific groups of countries, in certain time periods, or across some of the regime categories.

\section{DATA DESCRIPTION}

All the series are annual and cover the years 1970 to 2006 . Our analysis takes into consideration 25 emerging market economies ${ }^{1}$. The World Development indicators and International Financial Statistic are main sources for most of the independent variables. All the political variables are obtained from Database of Political Institution-2006. The variable representing capital account restriction (CAR) is taken from the paper by Prasad, et. al. (2003). Based on theoretical suggestions and empirical findings, we take into consideration three groups of potential exchange rate regime determinants: OCA fundamentals, macroeconomic aggregates, and political and institutional features. The exact construction of data and data sources are reported in the appendix. The explanatory variables, their symbols and definitions are as follows:

For OCA fundamentals, we include trade openness (OPENNESS, measured as imports plus exports as a share of GDP), geographical trade concentration (GEOGTRADE, measured by the share of the largest trade partner in total trade), inflation differential (INFLATION, measured as USA inflation minus domestic inflation), size of economy (GPD, measured by gross domestic product in logarithm), and level of economic development (GDPpercapita, measured by log of GDP per capita). The OCA theory says that more open economies want to adopt less flexible regimes while larger economies and economies with higher level of GDP per capita want to adopt more flexible regimes.

For macroeconomic aggregates, we employ current account deficit or surplus (CA, measured as current account deficit/surplus as a share of GDP), de facto 
capital account openness (CAOPENNESS; measured as sum of the absolute value of inward and outward gross capital as a ratio of GDP), reserves (RESERVES, measured as total reserves as a ratio of Imports), rate of growth of M2 (M2GROWTH, measured as annual growth rate of money plus quasi money), and terms of trade (TOT, measured as standard deviation of annual percentage change of terms of trade). The economic theory suggests that high reserves are associated with a fixed regime.

In an attempt to reflect the political and institutional features, we consider capital account restriction (CAR), period of duration of chief executive in office (YRSOFFC), a variable showing that executive parties have an absolute majority in assembly (MAJORITY), and a variable representing whether executive party is nationalist (NATINALIST) or not. All the OCA and macroeconomic variables are lagged one period to avoid potential endogeneity problems. Most of the previous studies imply that there is a negative relationship between political stability and flexibility of an exchange rate regime.

As a dependent variable, the de facto classification called natural classification by Reinhart and Rogoff (2003) and the de jure classification based on the IMF's classification are used. Natural classification is coded as follows ${ }^{2}: 1$ for pegged regimes, 2 for limited flexibility arrangements, 3 for managed floating, 4 for freely floating, and 5 freely falling. Freely falling is a new category introduced by the authors that indicates high inflation period in which annual inflation rate is higher than $40 \%$. We also use the more detailed version of natural classification including the fifteen different regimes. Reinhart and Rogoff (2003) classify exchange rate regimes into 15 and 6 subcategories. The last categories both in 15-way and 6-way classifications don't represent a exchange rate regime, and denote missing data category. So we exclude these categories from the classifications and regard them as 14-way and 5-way classifications in our empirical analysis.

Since natural classification classifies the regimes until the year 2001, the de facto classification is used in the estimated for the period 1970-2001. As a dependent variable, the new IMF exchange rate classification (the de jure classification) that has been in use since 1999 is employed in the analysis for the years 1999-2006, too. The de jure exchange rate regimes of countries are taken from the various IMF Annual Reports. In this classification the least flexible regime takes the lowest value while the most flexible regime takes the highest value: 1 for no separate legal tender, 2 for currency board, 3 other conventional fixed peg, 4 for pegged exchange rates within horizontal bands, 5 crawling bands, 6 for exchange rates within crawling bands, 7 for managed floating, and 8 for independently floating. In addition, we combine the IMF classifications before and after 1999 and construct a new dependent variable over the period 1996 to $2006^{2}$. 


\section{ESTIMATION STRATEGY}

In this section, we present the econometric model which is applied to test the determinants of exchange rate regimes in emerging economies for the period 1970-2006. We use a random effect ordered probit model for an unbalanced panel of 25 emerging market economies. We describe the choices of exchange rate regimes in our sample using a discrete variable $y_{i t}$, which takes a value of $y_{i t}=1$ if the least flexible regime selected by country $i$ in year $t$, and $y_{i t}=J$ for the most flexible regime. This choice based on the latent variable $y_{i t}^{*}$, which is a function of the variables discussed above. A larger value of the latent variable indicates that a more flexible regime is desirable for the country and period under consideration. Given the discrete nature of regime choices, we assume that a country chooses the least flexible regime, $y_{i t}=1$, if latent variable is below a certain threshold, $y_{i t}^{*} \leq m_{0}$. Similarly, the most flexible regime is chosen, $y_{i t}=J$, if the latent variable is above another threshold, $m_{j-1}<\mathrm{y}_{\mathrm{it}}^{*}$, with $m_{0}<m_{j-1}$.

$$
y_{i t}=\left\{\begin{array}{cc}
1 & \text { if } y^{*}{ }_{i t} \leq m_{0} \\
2 & \text { if } m_{0}<y^{*}{ }_{i t} \leq m_{1} \\
3 & \text { if } m_{1}<y^{*}{ }_{i t} \leq m_{2} \\
\cdot & \cdot \\
\cdot & \cdot \\
j & \text { if } m_{j-1}<y^{*}{ }_{i t}
\end{array}\right.
$$

where the $m_{s}$ is unknown cut point parameters (thresholds).

The estimated equation for the model is equation below.

$y^{*}{ }_{i t}=\beta^{\prime} X_{i t}+\varepsilon_{i t}$ for $i=1,2,3, \ldots . . . N$, and $t=0,1, \ldots . . T_{i}$

where $X_{i t}, \beta, t$ and $i$ represent are a vector of explanatory variables, a vector of coefficients, country and time respectively ${ }^{3}$. The estimates of the coefficients of the vector $X_{i t}$ and of the thresholds, i.e, $m_{1}<m_{2}<m_{3 \ldots}<m_{j-1}$ are obtained by maximizing the likelihood function by using the quadratic hill climbing algorithm.

\section{EMPIRICAL RESULTS}

In this section, we present the results of random effect ordered probit analyses, conducted by using the unbalanced panel data sets. We estimate several specifications both for the de jure and de facto classifications. The results of estimations are presented in Table 1. We estimate the four regressions varying across regime classifications and time periods. The results of the first and the second regression are obtained for the period 1970-2001 by using the 5-way classification (RR 5), and the 14-way classification (RR 14) developed by 
Reinhart and Rogoff (2003) as a dependent variable. The third and fourth regressions are estimated by using the new IMF classification and the combined IMF classification constructed by us respectively.

A positive sign of a coefficient means that an increase in the associated variable raises the probability of adopting a flexible exchange rate regime. Most of the signs of optimum currency variables in the first and the second regressions are found as expected. For example, the size of economy, level of development (geographical concentration of trade) are expected to have a positive (negative) sign and their signs are found to be positive (negative). Although the sign of openness is expected to be negative, it is found to be positive. In contrast to the variables mentioned above, inflation affects negatively the probability of selecting a flexible exchange rate regime. Although most of the signs are as expected, the size of economy in the regression I and, OPENNESS and GEOGTRADE in the regression II are statistically insignificant. MAJORITY is positive, but insignificant in both the two regressions.

RESERVES, YRSOFFC and NATIONALIST are negatively and significantly associated with a flexible regime while M2GROWTH, TOT, CAR are positively and significantly associated with a flexible regime. The result related to YRSOFFC says that political stability is in favor of adopting a fixed regime. Like YRSOFFC, the sign of NATIONALIST implies that nationalist governments want to adopt more fixed regimes. In the three regressions, the current account deficit /surplus and de facto capital account openness are statistically insignificant.

Most of the variables in the regressions III and IV used the de jure classification are statistically insignificant. In contrast to the expected sign, it is found that the level of development decreases the probability of adopting a flexible regime in both the regressions. Similarly, contrary to the expected sign, the geographic concentration of trade is significantly and positively associated with a flexible regime.

When the four regressions are taken into consideration, the only two variables (level of development and TOT) are statistically significant. Nevertheless, the level of economy has a positive sign in the regressions I and II, whereas it has a negative in the regressions III and IV. When the de facto and de jure classifications are compared to each other, it appears that the relationship between the de facto classifications and the determinants of exchange rate regimes are stronger than the relationship between the de jure classifications and the determinants of regimes. 


\section{CONCLUSION}

In this paper, we apply a random effect ordered probit model to estimate the determinants of exchange rate regimes in 25 emerging market economies. We consider a wide range of the potential regime determinants including the OCA fundamentals, macroeconomic aggregates, and political and institutional features. To avoid potentially misleading classification, we use two different measures of the dependent variable, namely de jure (official) and de facto (actual) choice of exchange rate regimes. The estimations of the de jure and de facto specifications generate different results for the variables. The de facto models produce a better fit. This is consistent with the notion that official regime changes carry a cost that exceeds the cost of changing the de facto regime, and that country use this as a policy instrument to adjust their exchange rate policy to macroeconomic developments earlier and faster than they respond with their official regime. Therefore, it can be said that the de facto classifications should be preferred in order to classify the exchange rate regimes in emerging economies. It is found that the de jure regimes are not enough to explain the relationship between the exchange rate policies and the variables. Almost all the macroeconomic and political variables in the de jure models are found to be statistically insignificant.

Based on the findings obtained from the de facto regressions, we may conclude that the choice of exchange rate regime adopted by 25 emerging economies for the period under discussion have been influenced by the level of economic development, inflation differential and political factors, and not influenced by the current account deficit/surplus, (de facto) capital account openness.

\section{End Notes}

(1) While determining emerging market economies, we use Morgan Stanley Emerging Market Index. This index includes 26 emerging economies. Owing to lack of data on Thailand, we exclude this country. The countries considered in this paper are Argentina, Brazil, Chile, China, Colombia, Czech Republic, Egypt, Hungary, India, Indonesia, Israel, Jordan, Korea, Malaysia, Mexico, Morocco, Pakistan, Peru, Philippines, Poland, Russia, South Africa, Sri Lanka, Thailand, and Turkey.

(2) The old IMF exchange rate classification before 1999 divides the exchange rate regimes into four categories: (1) pegged to single currency or currency basket, (2) limited flexibility, (3) managed floating, and (4) independent float. When we combine the old and new IMF classifications, categories 1 and 2 in the old classification are regarded as other conventional fixed pegs and exchange rates within crawling bands in the new classification respectively. Similarly, category 3 and 4 are received as managed floating, and independently floating in the new classification respectively.

(3) Note that the panel is unbalanced as $T_{i}$ varies across $i$. 


\section{Appendix}

Table 2: Definition of Variables and Sources

\begin{tabular}{|c|c|c|}
\hline Variable & Explanation & Database \\
\hline GDP & Log of GDP (constant 2000 US\$), lagged one period & WDI online \\
\hline GDPpercapita & $\begin{array}{l}\text { Log of GDP per capita (constant } 2000 \text { US\$), lagged one } \\
\text { period }\end{array}$ & WDI Online \\
\hline OPENNES & (Exports + Imports) / 2, lagged one period & IFS Online \\
\hline INFLATION & $\begin{array}{l}\text { inflation differential: domestic inflation minus USA } \\
\text { inflation, lagged one period }\end{array}$ & IFS Online \\
\hline GEOGTRADE & $\begin{array}{l}\text { Share of Export to the largest Trade Partner in total } \\
\text { Exports, lagged one period }\end{array}$ & DOT Online \\
\hline CAOPENNESS & $\begin{array}{l}\text { Sum of the absolute value of inward and outward gross } \\
\text { capital as a ratio of GDP, lagged one period }\end{array}$ & IFS Online \\
\hline $\mathrm{CA}$ & $\begin{array}{l}\text { Current account deficit or surplus as a share of GDP, } \\
\text { lagged one period }\end{array}$ & WDI online \\
\hline RESERVES & Total reserves in months of imports, lagged one period & WDI online \\
\hline M2GROWTH & $\begin{array}{l}\text { Annual Growth Rate of Money plus Quasi money, } \\
\text { lagged one period }\end{array}$ & IFS Online \\
\hline TOT & $\begin{array}{l}\text { Standard deviation of annual percentage change of } \\
\text { terms of trade }\end{array}$ & WDI online \\
\hline CAR & $\begin{array}{l}\text { Existence of Capital Account Restrictions, lagged one } \\
\text { period }\end{array}$ & $\begin{array}{r}\text { Prasad, et. al. } \\
(2003) .\end{array}$ \\
\hline YRSOFFC & How many years has the chief executive been in office? & DPI 2006 \\
\hline NATIONALIST & Nationalist ( 1 if yes) & DPI 2006 \\
\hline MAJORITY & $\begin{array}{l}\text { Does the party of the executive have an absolute } \\
\text { majority in the houses that have lawmaking powers? }\end{array}$ & DPI 2006 \\
\hline
\end{tabular}

\section{REFERENCES}

Berger, H., Sturm, J.-E., and De Haan, J., (2000), "An Empirical Investigation into Exchange Rate Regime Choice and Exchange Rate Volatility", CESifo Working Paper; No. 263.

Bernhard, W., and Leblang, D. (1999), "Democratic Institutions and Exchangerate Commitments", International Organization, 53 (1): 71-97.

Bleaney, M., and Francisco, M. (2005), "The Choice of Exchange Rate Regime: How Valid is the Binary Model?", CREDIT research paper, No: 05/02. 
Calvo, G. A., and C. M. Reinhart (2000), "Fear of Floating", NBER Working Paper, No: 7993.

Collins, Susan M., (1996), "On Becoming More Flexible: Exchange Rate Regimes in Latin America and the Caribbean," Journal of Development Economics, 51: 117-38.

Dreyer, Jacob S., (1978), "Determinants of Exchange Rate Regimes for Currencies of Developing Countries: Some Preliminary Results," World Development, 6: 437-45.

Edwards, S. (1996). "The Determinants of the Choice Between Fixed and Flexible Exchange Rate Regimes", NBER Working Paper, No: 5756.

Edwards, S. (1998), "Exchange Rate Anchors and Inflation: A Political Economy Approach", In: Eijffinger, S., Huizinga, H. (Eds.), Positive Political Economy: Theory and Evidence,. Cambridge University Press, Cambridge.

Ghosh, A.R., Gulde, A.-M., and Ostry, J., Wolf, H. (1997), "Does the Nominal Exchange Rate Matter?", NBER Working Paper, No: 5874.

Heller, H.R. (1978), Determinants of Exchange Rate Practices, Journal of Money, Credit, and Banking, 10: 308-321.

Holden P., M. Holden, and E. Suss, (1979), "The Determinants of Exchange Rate Flexibility: An Empirical Investigation," Review of Economics and Statistics, 61: 327-33.

Honkapohja, S., and Pikkarainen, P. (1994), "Country Characteristics and the Choice of the Exchange Rate Regime: Are Mini-Skirts Followed by Maxis?" in Exchange Rate Policies in the Nordic Countries, ed. by Johnny Åkerholm and Alberto Giovannini (London: Centre for Economic Policy Research).

IMF, various issues, (1996-2006), Annual Reports (International Monetary Fund: Washington DC)

Juhn, G., and Mauro, P., (2002), "Long-run Determinants of Exchange Rate Regimes: A Simple Sensitivity Analysis”, IMF Working Paper, No: 02/104.

Kato, I., and Uctum, M. (2005), Choice of Exchange Rate Regime and Currency Zones. http://userhome.brooklyn.cuny.edu/economics/muctum/WP.htm

Levy-Yeyati, E., Sturzenegger, F. (1999) Classifying Exchange Rate Regimes: Deeds vs. Words, http://ideas.repec.org/a/eee/eecrev/v49y2005i6p1603-1635.html

Levy-Yeyati, E., and Sturzenegger, F. (2005), "Classifying Exchange Rate Regimes: Deeds vs. Words", European Economic Review, 49 (6): 1603-1635. 
Levy-Yeyati, E., and Sturzenegger, F., and Iliana, R. (2007), "On the Endogeneity of Exchange Rate Regimes", http://ideas.repec.org/p/udt/wpbsdt/veintiuno.html

Markiewicz, A. (2006), "Choice of Exchange Rate Regime in Central and Eastern European Countries: An Empirical Analysis", Center for Economic Studies Working Paper.

Melvin, M., (1985), "The Choice of An Exchange Rate System and Macroeconomic Stability", Journal of Money, Credit, and Banking ,17 (4): 467478.

Meon, P.-G., and Rizzo, J.-M. (2002), "The Viability of Fixed Exchange Rate Commitments: Does Politics Matter? A Theoretical and Empirical Investigation.", Open Economies Review, 13 (2): 111-132.

Papaioannou, M. C. (2003), "Determinants of the Choice of Exchange Rate Regimes in Six Central American Countries: An Empirical Analysis", IMF Working Paper, No: 03/59.

Poirson, H. (2001), "How Do Countries Choose Their Exchange Rate Regime?", IMF Working Paper, No: 01/46.

Prasad, E. S., Rogoff, K., Wei, S. and Kose, M. A. (2003), "Effects of Financial Globalization on Developing Countries: Some Empirical Evidence", IMF, http://www.nber.org/ wei/data.html

Reinhart, C., and Rogoff, K. S., (2003), "The Modern History of Exchange Rate Arrangements: A Reinterpretation", http://www.wam.umd.edu/ $\sim$ creinhar/Papers.html

Rizzo, J.-M., (1998), "The Economic Determinants of the Choice of an Exchange Rate regime: a Probit Analysis", Economics Letters, 59: 283-287.

Savvides, A. (1990), "Real Exchange Rate Variability and the Choice of Exchange Rate Regime by Developing Countries," Journal of International Money and Finance, 9: 440-54.

Von Hagen, J., and Zhou, J. (2007), "The Choice of Exchange Rate Regimes in Developing Countries: A multinomial Panel Analysis", Journal of International Money and Finance, 26: 1071-1094.

Von Hagen, J., Zhou, J., (2005), "The Choice of Exchange Rate Regimes: An Empirical Analysis for Transition Economies", Economics of Transition, 13 (4): 679-703. 
HOW DO MACROECONOMIC AND POLITICAL VARIABLES AFFECT THE FLEXIBILITY OF EXCHANGE RATE REGIME?

Zhou, J. (2003), "The Choice of Exchange Rate Regimes in Developing Countries: A Multinomial Panel Probit Analysis". http://ideas.repec.org/p/cpr/ceprdp/.html 